\title{
Identifying Significant Personal and Program Factors that Predict Online EdD Students' Program Integration
}

\author{
Amanda J. Rockinson-Szapkiw \\ University of Memphis \\ Joe Holmes \\ Jacqueline S. Stephen \\ Mercer University
}

\begin{abstract}
Based on a synthesis of persistence theory and the empirical literature, an online doctoral program integration model was developed using data from 232 online EdD students. A predictive, correlation design and regression analysis were used to examine if personal factors (gender, race, age, marital status, and presence of children in the home) and program factors (stage in doctoral journey, synchronous interactions, cohorts, and orientations) could predict program integration. The entire model was significant. The variables of gender, race, participation in a cohort, and engagement in synchronous communication individually contributed to the variance in program integration.
\end{abstract} faculty

Keywords: Doctoral persistence; online; social integration; academic integration;

Rockinson-Szapkiw, A.J., Holmes, J., \& Stephen, J.S. (2019). Identifying significant personal and program factors that predict online EdD students' program integration. Online Learning, 23(4), 313-335. doi:10.24059/olj.v23i4.1579

\section{Identifying Significant Personal and Program Factors that Predict Online EdD Students' Program Integration}

Persistence of doctoral students has been discussed throughout the literature for decades. This discussion ensues as researchers continue to consistently report high attrition rates across both residential and online doctoral programs. For example, residential, doctoral attrition rates have been reported to range between $40 \%$ and $60 \%$ (Cassuto, 2013; Council of Graduate Schools, 2008, 2012). Some studies conducted on Doctor of Education (EdD) programs have reported attrition rates as high as 70\% (Bowen \& Rudenstine, 1992; Nettles \& Millett, 2006). Researchers have also purported that online program attrition rates are often $10 \%$ to $20 \%$ higher than programs offered in residence (Heyman, 2010; Holder, 2007; Rovai, 2002; Terrell, Snyder, \& Dringus, 2009). Smith (2010) documented that online dropout rates across programs range from $40 \%$ to $80 \%$, and Bawa (2016), in a review of the literature on retention in online courses, noted that online student dropout rates continue to exceed the 
residential student dropout rates. The persistently high attrition rates across distance education and doctoral programs necessitates understanding "the process of student retention [which] differs" (Tinto, 2006-2007, p. 4) across programs and mediums Castelló, Pardo, Sala-Bubaré, and SuñeSoler (2017), in a survey study of 724 social sciences doctoral students across 56 institutions, noted, that even though high doctoral attrition rates have been documented for decades, little is still known about the reasons for their persistence and attrition. However, students' integration is vital in preventing dropout, and more needs to be understood about how institutions can promote integration, and thus, persistence. This, therefore, the study explores factors related to online EdD students' integration which has been associated with degree completion in distance and doctoral programs (Davidson \& Wilson, 2013; Rockinson-Szapkiw, L.S. Spaulding, \& M.T. Spaulding, 2016; Rovai, 2003).

\section{Theoretical Framework}

Integration is a key factor associated with the decision to leave or stay in a doctoral program. The concepts of social and academic integration are central to Tinto's (1975) seminal persistence work. Tinto (1975) posited that in order to persist, undergraduate students need to integrate into academic (e.g., evidenced by GPA) and social systems (e.g., extracurricular activities) within the university. Later, extending his work to doctoral students, Tinto (1993) suggested that doctoral student persistence is "shaped by the personal and intellectual interactions that occur within and between students and faculty and the various communities that make up the academic and social systems of the institution" (p. 231). Researchers have applied Tinto's $(1975,1993)$ work to doctoral (Wao \& Onwuegbuzie, 2011) and online education (Rovai, 2003). Many have found academic integration and social integration associated with online and doctoral student persistence (Castelló et al., 2017; Ivankova \& Stick, 2007; Rockinson-Szapkiw et al, 2016). Yet, other researchers have questioned the validity of academic integration and social integration as mutually exclusive constructs (Braxton \& Lien, 2000; Braxton, Sullivan, \& Johnson, 1997), especially for doctoral students (Lovitts, 2001; Tinto, 1993).

In an instrument validation study, Holmes and Rockinson-Szapkiw (2019) found that academic and social integration are intertwined for doctoral students in online programs. They purported that persistence is related to the term identified as program integration and is distinguished by who or what the integration is with (Holmes \& Rockinson-Szapkiw, 2019). In other words, program integration is comprised of three factors - faculty integration, student integration, and curriculum integration. Faculty integration is online, doctoral students' satisfaction with both the quality and nature of the interaction the student has with faculty. This includes the academic interactions (e.g., instruction, receiving timely feedback) as well as nonacademic interactions (e.g. social, empathy, care). Similarly, student integration is students' satisfaction with both the quality and nature of peer interactions within the program, both academic and non-academic. Finally, curriculum integration is the satisfaction a doctoral student has with the quality and relevancy of the doctoral curriculum (Holmes \& RockinsonSzapkiw, 2019). Drawing upon the work of Holmes and Rockinson-Szapkiw (2019), we examined the factors that predict the program integration of online, doctoral students enrolled in EdD programs. 


\section{Review of Literature}

Literature on doctoral and online students has revealed a myriad of factors are associated with both integration and persistence (Tinto, 1975; Bean \& Metzner, 1985; Rovai, 2003). Personal factors, such as family, gender, race, ethnicity, and age can influence student integration and impact persistence. Additionally, program factors, such as stage, cohort, technology, and orientation can also affect students' integration and persistence.

\section{Personal Factors}

Marital status and presence of children in the home. Doctoral literature, focusing on both online and residential students, has shown that familial factors are of great significance to doctoral students' pursuit, integration, and persistence. In a grounded theory study aimed at explaining the persistence of online, doctoral students from backgrounds of poverty, Rockinson-Szapkiw, Spaulding, Swezey, and Wicks (2014) found that doctoral students' family members were motivators to complete the program. These findings support previous doctoral persistence research establishing an association between the family and doctoral persistence (Lott, Gardner, \& Powers, 2009; Rockinson-Szapkiw et al., 2016). Having a supportive spouse is documented as a factor in doctoral program cess success. In a phenomenological inquiry, Spaulding and Rockinson-Szapkiw (2012) analyzed data from 76 individuals who completed their doctoral degrees in education across both online and residential programs. They noted that a spouses's encouragement and support can provide the motivation needed to integrate and persist (Spaulding \& Rockinson-Szapkiw, 2012).

In addition to being a spouse or partner, an online doctoral learner can be a parent, guardian, and primary caregiver (Baker, 2014; West, 2014). While many doctoral students attribute persistence to family support, many also report poor degree progression and integration associated with balancing their doctoral studies and families (Dabney \& Tai, 2013). In a number of qualitative studies, doctoral students, namely women, explained that being married and having children during a doctoral can be stressful and salient in their lack of academic integration and persistence (Oswalt \& Riddock, 2007; Rockinson-Szapkiw, Spaulding, \& Lunde, 2017; Rockinson-Szapkiw, 2019; Smith, Maroney, Nelson, Abel, \& Abel, 2006). For example, Brown and Watsons (2010) interviewed nine women enrolled in a residential Ph.D. program who identified three primary stressors, which included (a) the conflict between their roles as mothers and students, (b) the consistent balancing act of home and academic responsibilities, and (c) time for academics being slighted by family demands and responsibilities. Doctoral work often gets in the way of familial obligations, with students missing children's sports activities, dinners out, and even vacations due to program requirements (Spaulding \& Rockinson-Szapkiw, 2012). These conflicting demands can have negative physical and emotional effects, leading to burnout, a break down, and increased timeto-degree (Rockinson-Szapkiw, et al., 2017; Wao \& Onwuegbuzie, 2011), causing students to make difficult choices between their conflicting demands (Tinto, 1993). Other researchers have found that students who report being satisfied with the balance between academic work and personal or familial domains are more motivated to persist (Tanaka \& Watanabea, 2012) and are less likely to voice the intention to drop out (Castelló et al., 2017). Having or not having children may influence an online, doctoral students' program integration as numerous studies have shown an association with having children, particularly for women, and lower levels of doctoral success (Brown \& Watson, 2010; Dabney \& Tai, 2013; Rosser \& Lane, 2002). 
Race, gender, and age. Theories and models for attrition and persistence have revealed student characteristics, such as age, gender, and race, influence integration and persistence (Tinto, 1975; Bean \& Metzner, 1985; Rovai, 2003). Ongoing research has supported demographic factors as salient to both persistence and attrition. In one study, questions drawn from critical race theory were used to elicit narratives from Black and Latinx doctoral students for an ethnographic study on everyday lived experiences of racial and ethnic minorities (Gildersleeve, Croom, \& Vasquez, 2011). Findings demonstrated that barriers to integration at the program and course levels existed due to several factors, such as self-censorship, lack of confidence, and the pronounced expectation to conform to established rules and gender and racial norms. These factors hindered scholarly aspirations and presented barriers to persistence. The findings are consistent with persistence and attrition models (Tinto, 1993; Bean \& Metzner, 1985; Rovai, 2003) that demonstrated students who do not feel they "fit in" due to their race or gender are more likely to withdraw due to isolation. Student age has also been recognized as a characteristic that can impact persistence in adult learners (Tinto, 1993; Rovai, 2003), and age is a common variable that can impact nontraditional student persistence (Bean \& Metzner, 1985). Gender, race, and age are factors that are often included in studies where a better understanding of doctoral attrition and persistence is sought (Castello et al., 2017; Gardner, 2009; Ellis, 2001).

\section{Program Factors}

Program stage. Although Tinto (1993) was not specific to online doctoral students, he suggested and the that membership in a community is beneficial to all doctoral students, but that levels of integration varies across doctoral program stages (Tinto, 1993). Similarly, other researchers have contended that students should be integrated throughout each stage of the doctoral journey (Gardner, 2009; Grover, 2007; Terrell et al., 2009; Tinto, 1993; Wao \& Onwuegbuzie, 2011); however, integration ateach stage may take a different form and be dependent upon different people. Stage one is comprised of the first one-to-two years (the initial coursework stage) when students begin to integrate into their program, building initial relationships with peers and faculty (Rockinson-Szapkiw \& Spalding, 2014). In stage two, student integration becomes more localized as communities comprised of the same student and faculty groups develop, and students acquire the knowledge and skills needed in their respective fields of study. In stage three (from candidacy through defense), the communities generally shrink to the students and faculty involved in the dissertation (Tinto, 1993). As students transition from the coursework stage of their doctoral journey to the more independent structure of the dissertation phase, researchers have demonstrated over and over that integration with social networks and supportive faculty are primary to their persistence (Ali \& Kohun, 2007; Terrell et al., 2009; Zahl, 2015). However, at this final stage, students are more likely to feel disconnected and drop out due to a lack in sense of belonging or community (Terrell et al., 2009).

Cohort. In doctoral programs, cohorts have been defined as "a group of about 10-25 students who begin a program of study together, proceed together through a series of developmental experiences in the context of that program of study, and end the program at approximately the same time" (Lei, Gorelick, Short, Smallwood, \& Wright-Porter, 2011, pp. 497-498). Research has demonstrated that a cohort can support doctoral students by encouraging interaction, providing structure, fostering cohesiveness, and providing opportunities for scholarship and practice. In a case study of residential educational doctoral 
programs, Bista and Cox (2014) found that students reported the cohort model as a structure that enabled faculty and peer support throughout the program. In a qualitative case study, Berry (2017) explored how first and second-year students in an online EdD doctoral program created a community. Findings demonstrated that online doctoral students' sense of community was derived from participation in cohorts, class groups, small peer groups, and study group. Cohorts were described as the "largest social sphere of influence within the program" (Berry, 2017, p. 39). Berry (2017) further suggested that the cohort provided structure and cohesion for students. It is this form of the established community via cohorts that Tinto (1993) suggested increased the likelihood of academic and social integration.

Online Communication, Synchronous, and Asynchronous. Throughout the online education literature, it is documented that connection with faculty members in the online environment is vital to students' integration into learning communities (Provident et al., 2015; Rademaker et al., 2016), and teaching presence, with the associated social presence, can be supported online through the use of technology (Rockinson-Szapkiw, Baker, Neukrug, \& Hanes, 2010). Ivankova and Stick (2007) conducted a mixed methods study, surveying 278 doctoral online students within Doctor of Education programs and following up with in-depth interviews. A significant finding of the study was that doctoral students who persisted felt a high level of comfort with technology and online systems; they held the belief that the online environment was able to provide a doctoral experience comparable to a residential programme. For many students who successfully matriculate, the asynchronous communication provided the opportunity for deep reflection and created a learning environment conducive to their learning preferences (Ivankova \& Stick, 2007). However, online doctoral students in other studies have reported that balanced use of both synchronous and asynchronous communication enhanced their sense of connection with faculty and peers, and ultimately, persistence (Teng, Chen, Kinshuk, \& Leo, 2012; Fuller, Risner, Lowder, Hart, \& Bachenheimer, 2014). Maul, Berman, and Ames (2018), in an exploratory case study of online doctoral programs (e.g., $\mathrm{DBA}, \mathrm{EdD}$, and $\mathrm{PhD}$ ) in the dissertation phase, found that the use of online video coaching improved academic success, belonging and integration, and ultimately retention. The researchers also noted that the frequency of use may influence a doctoral students' success.

Orientation. Research findings also support the inclusion of orientation activities centered on student integration with faculty, advisors, and other students (Motte, 2019; Rosenblatt \& Christensen, 1993; Taub \& Komives, 1998). One study into patterns of attrition found that while it is at its highest during the first two years of a program, it also occurred during other stages (Di Pierro, 2007). As a result, research has recommended that orientation programs incorporate integration opportunities that span the duration of the journey, from students meeting their peers and program faculty at the onset of the program (Motte, 2019) to regular contact with a program advisor and dissertation chair during the final stage (Gittings, Bergman, Shuck, \& Rose, 2018).

\section{Current Study}

The literature, which has been primarily qualitative in nature and focused on residential doctoral students, suggests a myriad of factors may be associated with the integration of online, EdD students. While these studies provide insight into factors associated with online doctoral students' integration, there is a need to examine these factors from a quantitative perspective. Therefore, grounded in persistence theory (Tinto, 1975, 1987, 1993) and research on distance doctoral integration (Holmes \& Rockinson-Szapkiw, 2019), a model was created to examine 
the personal and program factors associated with online EdD students' program integration (see Figure 1). A multiple regression, a common method of predicting and modeling in educational (Warner, 2013), was used.

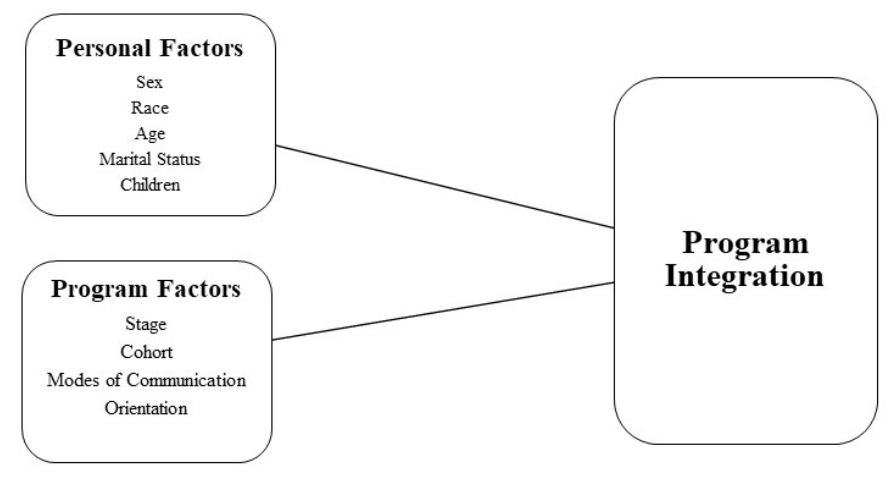

Figure 1. Model

Additionally, recognizing the variation across doctoral programs in education, we delimited this study to EdD programs who are part of the Carnegie Project for the Education Doctorate (CPED) initiative or have identified as professional EdD programs. For nearly 100 years, the debate has existed surrounding the distinction between the EdD and $\mathrm{PhD}$ in education (Perry, 2013). The Carnegie Project for the Education Doctorate (CPED) was created as "the first action-oriented effort to distinguish the EdD as a professional practice degree" (Perry, 2013, p. 113). Professional doctoral programs are distinguished as they bring together theory and practical application with the aim of creating a practitioner degree that better prepare leaders in education (Perry, 2013). The dissertation is often conducted in a practical application setting (Lee, Green, \& Brennan, 2000; Maxwell, 2003).

\section{Methods}

\section{Participants and Setting}

Via a convenience and snowball sampling, in Spring of 2018, data were collected from 232 students enrolled in an online, professionally-focused Doctor of Education (EdD) programs at both public and private institutions. Researchers sent out emails and posted via professional organization listservs invitation to participate in an anonymous survey. In the invitation, the criteria for participation were outlined and students verified eligibility through a series of survey questions: 1) participation in a CPED or professional-focused EdD program and 2) participation in a program in which $80 \%$ of course work is taken online. Students 
reported that their online Doctor of Education (EdD) programs required between 54 and 63 credit hours.

The demographics of this sample were consistent with the National Science Foundation Report (2019) that demonstrates women and Caucasians were the primary recipients of social science and educational doctorates in the U.S. The majority of participants in this study were Caucasian $(n=179,77.2 \%)$ and women $(n=174,75 \%)$. There were also $33(14.2 \%)$ African American, 12 (5.2\%) Hispanic, 3 (1.3\%) Asian, 1 (.4\%) American Indian, and $4(1.7 \%)$ other classified participants. The majority reported their age range as 30-39 $(n=63,27.2 \%)$ or 40 $49(n=85,36.6 \%)$. Most of the students were married $(n=187,80.6 \%)$ with a little over half having children under 18 living in the home $(n=125,53.9 \%)$. Almost all of the participants worked full time ( $n=133,89.9 \%$ ) having positions as $\mathrm{K}-12$ teachers, $\mathrm{K}-12$ administrators, counselors, university staff, higher education faculty, and higher education administrators.

\section{Instrumentation}

The participants completed an online survey that consisted of validated instruments and researcher developed questions. Program integration served as the criterion variable and was measured using the Distance Doctoral Program Integration Scale (DDPIS; Holmes \& Rockinson-Szapkiw, 2019). The 32-item self-report instrument measures faculty integration, student integration, and curriculum integration. Faculty integration represents satisfaction that doctoral students have with their faculty interactions, including both the quality and nature of those interactions. Student integration is the satisfaction level students feel with peer interactions. Finally, curriculum integration represents the level of satisfaction with the doctoral curriculum's quality and relevance. The results of an exploratory factor analysis demonstrated that the three subscales were latent dimensions of program integration. Cronbach's coefficient alpha for the full scale was .86. In the present study, the Cronbach alpha coefficient for full scale, which was used in this study to measure the criterion variable of program integration, is .93. The instrument contained statements such as the personal relationships you developed with your fellow students and how you are finding the coursework in your program to be a good fit for you. Respondents are asked to rate their level of satisfaction with the potential responses of highly satisfied (5) to highly dissatisfied (1). Scores ranged from 1-5, with higher scores indicating higher integration.

Program and personal variables served as the predictor variables in the study and each was assessed using single survey items. In some incidences the use of multiple items to measure a construct is preferable as it can increase the reliability (DeVellis, 2003); however, the precedent has been set that a well-worded item can measure a construct (e.g., Postmes, Haslam, \& Jans, 2013). Moreover, it can be argued that the use of multiple items to measure a construct may result in common method variance, where "systematic error variance shared among variables measured with and introduced as a function of the same method and/or source" (Richardson, Simmering, \& Sturman, 2009, p. 762). Considering the precedent and the literature, as well as the information we sought to ascertain, a single item was used to assess each program and personal variable. These predictor variables and the items used to measure each is summarized in Table 1. 
Table 1.

Variables

\begin{tabular}{|c|c|c|}
\hline Variable & Survey Question & $\begin{array}{l}\text { Survey answer (dummy code or } \\
\text { Likert-type scale) }\end{array}$ \\
\hline \multicolumn{3}{|l|}{ Personal } \\
\hline Gender & Please indicate your gender. & $\begin{array}{l}\text { Male }(1) \\
\text { Female }(0)^{* *}\end{array}$ \\
\hline Race & Please indicate your race. & $\begin{array}{l}\text { Caucasian (1) } \\
\text { Black (0) } \\
\text { Asian (0) } \\
\text { Hispanic (0) } \\
\text { American Indian (0) } \\
\text { Other (0) }\end{array}$ \\
\hline Age & Please indicate your age range. & $\begin{array}{l}\text { Under } 19(1) \\
20-29(2) \\
30-39(2) \\
40-49(4) \\
50-59(5) \\
60-69(6) \\
70-79(7) \\
80-89(8)\end{array}$ \\
\hline Marital Status & What is your marital status? & $\begin{array}{l}\text { Married (1) } \\
\text { Single (0) } \\
\text { Widowed (0) } \\
\text { Divorced (0) } \\
\text { Other }(0)\end{array}$ \\
\hline Children & $\begin{array}{l}\text { Do you have children in your home under the age of } \\
18 ?\end{array}$ & $\begin{array}{l}\text { Yes }(1) \\
\operatorname{No}(0)\end{array}$ \\
\hline Stage & What stage of the program are you in? & $\begin{array}{l}\text { Course work, year } 1 \text { (1) } \\
\text { Course work (year } 2 \text { or } 3 \text { ) up to } \\
\text { comprehensive exam (2) } \\
\text { Dissertation (proposal) (3) } \\
\text { Dissertation (research, passed } \\
\text { proposal defense) (4) }\end{array}$ \\
\hline Cohort & Are you part of a doctoral cohort? & $\begin{array}{l}\text { Yes (1) } \\
\text { No(0) }\end{array}$ \\
\hline $\begin{array}{l}\text { Synchronous } \\
\text { Communication }\end{array}$ & $\begin{array}{l}\text { How often do you participate in real-time (synchronous) } \\
\text { program-related activities using web-based or mobile } \\
\text { technology (e.g., live lectures, live discussions, live } \\
\text { study groups, etc.)? }\end{array}$ & $\begin{array}{l}\text { Weekly } \\
\text { Monthly } \\
\text { Every 2-3 months } \\
\text { Every 4-6 months } \\
\text { About 1-2 times a year } \\
\text { Less than once a year } \\
\text { Never }\end{array}$ \\
\hline Orientation & Did you complete an orientation for your program? & $\begin{array}{l}\text { Yes }(1) \\
\text { No }(0)\end{array}$ \\
\hline
\end{tabular}

**Note. The other was included as an option, but it was not chosen as an answer by any participant.

\section{Analysis and Findings}

A hierarchical multiple regression analysis was conducted to examine how program integration can be explained by personal and program factors. This analysis was chosen as it is commonly used when researchers want to understand the relationship between predictor variables and a continuous criterion variable (Warner, 2013). Variables were entered into the model using temporal order and as guided by the literature. For example, personal factors were added into the model first as the students entered their doctoral program with these factors 
present. Assumption testing was completed prior to conducting the analysis. IBM SPSS version 25 was used to analyze the data.

\section{Descriptive Statistics, Correlations, and Assumption Tests}

Descriptive statistics for predictor and criterion variables are reported in Table 2. The mean and standard deviation for program integration is reported for each nominal variable.

Table 2.

Descriptive Statistics $(N=232)$

\begin{tabular}{|c|c|c|c|c|}
\hline & Variable & $M$ & $S D$ & $n$ \\
\hline \multicolumn{2}{|c|}{ Program Integration (Criterion Variable) } & 2.32 & .73 & - \\
\hline \multicolumn{5}{|c|}{ Personal Factors (Predictor Variables) } \\
\hline \multirow[t]{2}{*}{ Gender } & Female & 2.075 & .159 & 174 \\
\hline & Male & 2.433 & .180 & 58 \\
\hline \multirow[t]{2}{*}{ Race } & Caucasian & 2.448 & .159 & 177 \\
\hline & Other & 2.061 & .181 & 55 \\
\hline \multirow[t]{8}{*}{ Age } & 19 and under & & & 0 \\
\hline & $20-29$ & 2.483 & .186 & 16 \\
\hline & $30-39$ & 2.429 & .101 & 63 \\
\hline & $40-49$ & 2.449 & .101 & 85 \\
\hline & $50-59$ & 2.357 & .124 & 46 \\
\hline & $60-69$ & 2.491 & .178 & 20 \\
\hline & $70-79$ & 1.584 & .668 & 1 \\
\hline & Over 80 & 1.986 & .668 & 1 \\
\hline \multirow[t]{2}{*}{ Marital Status } & Married & 2.233 & .153 & 187 \\
\hline & Other & 2.233 & .153 & 45 \\
\hline \multirow[t]{2}{*}{ Children } & Yes & 2.239 & .180 & 125 \\
\hline & No & 2.269 & .160 & 107 \\
\hline \multicolumn{5}{|c|}{ Program Factors (Predictor Variables) } \\
\hline \multirow[t]{2}{*}{ Cohort } & No & 2.014 & .159 & 180 \\
\hline & Yes & 2.494 & .182 & 52 \\
\hline \multirow[t]{2}{*}{ Orientation } & No & 2.279 & .166 & 134 \\
\hline & Yes & 2.230 & .171 & 98 \\
\hline \multirow[t]{4}{*}{ Stage } & Course work, year 1 & 2.205 & .182 & 39 \\
\hline & $\begin{array}{l}\text { Course work (year } 2 \text { or } 3 \text { ) up to the } \\
\text { comprehensive exam }\end{array}$ & 2.355 & .182 & 63 \\
\hline & Dissertation (proposal) & 2.203 & .176 & 70 \\
\hline & $\begin{array}{l}\text { Dissertation (research, passed } \\
\text { proposal defense) }\end{array}$ & 2.254 & .184 & 60 \\
\hline \multirow{7}{*}{$\begin{array}{l}\text { Synchronous } \\
\text { Communication }\end{array}$} & Weekly & 2.433 & .181 & 38 \\
\hline & Monthly & 2.496 & .185 & 27 \\
\hline & Every 2-3 months & 2.211 & .183 & 22 \\
\hline & Every 4-6 months & 2.213 & .281 & 8 \\
\hline & About 1-2 times a year & 2.118 & .211 & 43 \\
\hline & Less than once a year & 2.052 & .188 & 37 \\
\hline & Never & 1.987 & .194 & 57 \\
\hline
\end{tabular}


A correlation matrix demonstrating the association among the predictor variables (see Table 3) was completed. While most of the bivariate correlation coefficients, including Pearson's $r$, Spearman $\rho$, and point-biserial correlation, were not statistically significant, some were. The bivariate correlation coefficients that were statistically significant had small effect sizes considering Cohen's (1992) conventions (i.e. $0.1<|r|<.3=$ small, $0.3<|r|<.5=$ moderate; and $|r|>.5=$ strong).

Table 3.

Correlation matrix $(N=232)$

\begin{tabular}{cccccccccc}
\hline & 1 & 2 & 3 & 4 & 5 & 6 & 7 & 8 & 9 \\
\hline 1 & - & $.135^{*}$ & 0.0 & 0.1 & 0.0 & -0.1 & 0.1 & 0.1 & $.151^{*}$ \\
2 & & - & 0.0 & $.137^{*}$ & 0.0 & -0.1 & 0.0 & 0.1 & 0.1 \\
3 & & & - & 0.1 & $.323^{* *}$ & $.187^{* *}$ & $-.150^{*}$ & -0.1 & 0.1 \\
4 & & & & - & $-.268^{* *}$ & $.234^{* *}$ & 0.0 & 0.1 & 0.1 \\
5 & & & & & - & 0.0 & 0.0 & 0.0 & 0.0 \\
6 & & & & & & - & 0.0 & 0.1 & $.170^{* *}$ \\
7 & & & & & & & - & -0.1 & 0.0 \\
8 & & & & & & & & - & $.294^{* *}$ \\
9 & & & & & & & & & - \\
\hline
\end{tabular}

Note: Predictor Variable (PV) Key: $1=$ gender, $2=$ race, $3=$ age, $4=$ marital status, $5=$ children in home (18 or under), $6=$ stage, $7=$ synchronous communication, $8=$ cohort, $9=$ orientation.

*Correlation is significant at the 0.05 level (2-tailed).

**Correlation is significant at the 0.01 level (2-tailed).

After calculating the descriptive statistics and prior to conducting the analyses, we conducted assumption tests for the six assumptions associated with a hierarchical multiple regression in order to ensure the robustness of the analysis with the data set, including (1) independence of observations, (2) linearity, (3) homoscedasticity, (4) multicollinearity, (5) no significant outliers, and (6) normality. No gross assumption violations were found, so the chosen parametric analyses were deemed robust and we continued by conducting the hierarchical linear regression analysis.

\section{Results}

We found that personal factors played a significant role in explaining program integration $(F(5,226)=8.56, p<.001)$. Examination of the coefficient demonstrated that $15.9 \%\left(R^{2}=.159\right)$ of the variance in program integration was explained by personal factors. When the program factors were added to the regression model, the model improved significantly $\left(F_{\text {change }}(4,222)=8.21, p<.001, R^{2 \text { change }}=.108\right)$. The entire model containing the combination of the personal and program variables was significant $(F(9,222)=9.01, p<.001)$, explaining $26.8 \%$ of the variance in online EdD students' program integration. Several variables made individual significant contributions to explaining program integration, including gender, race, participating in a cohort, and participating in synchronous meetings (see Table 4). Examination of the mean scores demonstrated that men and Caucasians on 
average had higher program integration scores than their women and minority counterparts (see Table 1). Online EdD students who participated in cohorts also perceived higher program integration than those that did not. Finally, as the frequency of synchronous communication increased, so did the student's program integration.

\section{Table 4.}

Hierarchical Regression Analysis Results for Both Blocks

\begin{tabular}{|c|c|c|c|c|c|c|c|}
\hline & $R^{2}$ & $F$ Ratio & $B$ & $S E$ & $\beta$ & $t$ & $p$ \\
\hline Block 1* & .159 & 8.56 & & & & & $<.001$ \\
\hline Block 2* & .268 & 9.01 & & & & & $<.001$ \\
\hline Gender* & & & .388 & .099 & .232 & 3.901 & $<.001$ \\
\hline Race* & & & .374 & .101 & .219 & 3.715 & $<.001$ \\
\hline Age & & & -.030 & .043 & -.045 & -.690 & .491 \\
\hline Marital Status & & & -.053 & .117 & -.029 & -.455 & .649 \\
\hline Children & & & .036 & .094 & .025 & .384 & .701 \\
\hline Stage & & & -.007 & .043 & -.010 & -.170 & .865 \\
\hline Synchronous* & & & .072 & .019 & .220 & 3.748 & $<.001$ \\
\hline Cohort* & & & .483 & .106 & .278 & 4.539 & $<.001$ \\
\hline Orientation & & & -.013 & .091 & -.009 & -.140 & .889 \\
\hline
\end{tabular}

Note. $* p<.05$

\section{Discussion}

Predictors examined included the personal variables (i.e., gender, race, age, marital status, and presence of children in the home) and the program variables (i.e., stage in the program, the presence of synchronous interaction, use of a cohort model, and participation in an orientation). The entire model was found to significantly predict online EdD students' program integration; thus, the findings cohere with previous research (e.g., Earl-Novell, 2006; Wao \& Onwuegbuzie, 2011) and theory (Tinto, 1993). The variables of gender, race, being part of a cohort, and participating in synchronous meetings made significant individual contributions in explaining the variance in program integration.

Men and Caucasians were found to have higher program integration scores than their peers who were women and minorities. These findings are not surprising. While women may be the majority in online education doctoral programs, women and racial and ethnic minorities may experience difficulty integrating into the male-dominant and White social structures that dominate the online and higher education environment similar to the residential environment (Gardner, 2013; Rockinson-Szapkiw, Spaulding, \& Lunde, 2017; Ward \& Wolf-Wendel, 2017; von Prummer \& Rossie, 2001). For example, in a qualitative study of women enrolled in an online EdD program, Rockinson-Szapkiw et al. (2017) purported that gendered norms and gendered communications negatively influenced women's integration and persistence. Within the findings, the researchers relayed the story of one participant who reported thoughts of leaving after experiencing several negative, gendered interactions with a male dissertation chair. Despite the fact that some researchers have noted that stereotypes are reduced in the online environment, other researchers have documented that minority student's experience in doctoral education has also been characterized as oppressive and dehumanizing (Gay, 2004), Underrepresented minority 
students and women across STEM and non-STEM doctoral programs report experiencing macroaggressions, which negatively influences students' sense of belonging and integrations (O’Meara, Griffin, Kuvaeva, Nyunt, \& Robinson, 2017). This lack of integration related to negative stereotype and representation of races and gender has been found to influence doctoral degree completion rates (Ostrove et al., 2011) Moreover, scholars have noted that the online environment is "yet another institution where gender and power differences are constructed, and to ignore the ways that gender is under construction online is to ignore many difficult experiences of real people" (Kramarae, 2003, p. 269).

Normative gender roles associated with women may also make integration difficult. Expectations to do the majority of emotional (Erikson, 2005), material (Hochschild \& Machung, 2012) and familial work often are placed upon women. Throughout the doctoral literature, women have more readily articulated the struggle between having a family and being a doctoral student (Hyun, Quinn, Madon, \& Lustig, 2006; Rockinson-Szapkiw, Spaulding, \& Lunde, 2017). Reportedly, women are advised by social systems, both internal and external to the higher education institution, to drop out of their doctoral programs when their doctoral responsibilities come in conflict with their familial ones. This is in contrast to the experience of men. A man's family members, not the man, is encouraged to sacrifice for the sake of the doctoral program (Carter, Blumenstein, \& Cook, 2013). Consistent with previous theories, models, and literature on doctoral and online students (Tinto, 1975; Bean \& Metzner, 1985; Rovai, 2003), the findings of this study demonstrated that both personal factors, as well as program factors, affect students' integration. Women and minority populations may experience struggles related to gender and racial norm online similar as they so in residential programs, leading to poorer program integration.

Online EdD students who participated in cohorts also perceived higher program integration than those that did not. These findings also similar with previous research on doctoral program structure (Bhandari et al., 2013; Shacham \& Od-Cohen, 2009). Cohort models provide a structure that facilitates peer and faculty interactions; thus, increasing students' satisfaction with the nature and quality of interactions they have throughout the program (Bista \& Cox, 2014). Those online EdD students not in a cohort may find it more difficult to connect with peers, for they may only have the opportunity to interact with a particular peer in one or two classes (Garrison \& Arbaugh, 2007; Moore, 1989; Terrell et al., 2009).

Finally, as the frequency of synchronous communication increased so did students' program integration. Technologies offer opportunities for sustained communication and interaction between faculty and students (Rockinson-Szapkiw, et al., 2010); therefore, integration in an online course can be supported through the frequent use of synchronous web technologies, such as video conferencing software as previous research has found (Maul et al., 2018).

While the factors of age, marital status, stage in the program, and participation in an orientation did not make significant individual contributions, they were part of the model that was found to be significant. Although the regression analysis provided a useful tool for modeling the dependence of the program integration variable on the multiple variables, the analysis did not allow for complex modeling of interactions among variables. Therefore, more sophisticated modeling in future research is needed to further understand the significance and interaction of each variable in predicting program integration. 


\section{Implications}

The results of this research indicated personal factors (i.e., gender, race, age, marital status, and presence of children in the home) and program factors (i.e., stage in the program, the presence of synchronous communication, use of a cohort model, and participation in an orientation) significantly predicted online EdD students' program integration. Doctoral conferring institutions and educators have the responsibility to support their online students' program integration and, thus, promote their persistence. By understanding how personal and program factors influence program integration, decision-makers can develop and implement interventions designed to increase satisfaction levels with the curriculum, peer integration, and faculty integration, thereby increasing doctoral student persistence.

The results in this study suggested that doctoral students in a cohort have higher program integration. While arguments have been made that implementing a cohort model can reduce the flexibility of a program for busy adult learners, a cohort provides a structure that supports peer connectedness. This connectedness can increase the likelihood of integration and persistence (Lovitts, 2001; Rovai, 2003). These authors, like Shulman (2010), argue for the use of a cohort experience in professional doctoral programs as the experience help doctoral students to integrate academically and provide social support throughout the degree process.

Findings also supported the frequent use of synchronous meeting to support connection and integration with peers and faculty, which many online doctoral students find difficult (Garrison \& Arbaugh, 2007; Moore, 1989; Terrell et al., 2009). Therefore, specific actions to promote student-student, student-faculty, and student content are needed. Ivankova and Stick (2007) posited frequent interactions using online methods to interact promotes the creation of virtual communities. Rockinson-Szapkiw (2011) suggested creating "collaborative web-based workspace[s] to share documents and to facilitate ongoing discourse" (p. 1166) can increase factors associated with integration with peers, faculty, and the curriculum. Without connections and interactions, doctoral students may begin to feel isolated, and feelings associated with isolation have been found to be "the most frequently cited integration-related reasons" (Lovitts, 2001, p. 177) for departure. These findings also suggested that program and course level synchronous meetings should also be integrated into the program and curriculum to decrease isolation and increase integration.

Results in this study indicated women and monitories scored lower in their program integration than their Caucasian and male peers. As such, it is imperative to educate faculty on gender and racial differences. Specifically, institutions should develop programs that help faculty understand social, economic, political, educational, and cultural effects, internal and external to the institution, that race and gender may have had and may continue to have, and how those differences may affect integration and persistence. Consideration of gendered communication (Rockinson-Szapkiw et al., 2017), having a "personal touch" (Zhao et al., 2007), and recognizing and the unique experiences of women and underrepresented minorities in research training (McGee, 2016) are central to the doctoral students' satisfaction with the advisory relationship, which ultimately influences belonging and integration into the institution and discipline. Therefore, race and gender need to be considered in advising or mentoring relationship faculty develops with online doctoral students.

Numerous studies have found the fit between faculty advisor and student greatly influences doctoral students' integration and persistence (Golde, 2005; Leijen, Lepp, \& 
Remmik, 2016; Litalien \& Guay, 2015; Lovitts, 2008), so diversity in faculty teaching in online programs should be ensured. For example, women may benefit from women advisors, mentors, committee members, and chairs they perceive to be more understanding of their life challenges (Rockinson-Szapkiw et al., 2017). By understanding personal and program factors that influence program integration, educators and doctoral students can better address integrationrelated issues and promote online doctoral student persistence.

Finally, race and gender should also be considered in supports developed for online doctoral students. For example, Rockinson-Szapkiw, Sosin, and Spaulding (2018) and Rockinson-Szapkiw et al. (2017), in studying women in online professional doctoral programs, noted that persistence and integration are connected to a women's ability to navigate the struggles of balancing family and academic work as well as integrate racial and gender identity dimensions with the developing scholar identity. Women and minorities in classes or via online support groups should be encouraged to share sacrifices, struggles, and accomplishments, which can be sources of inspiration and support for others (Marso, 2006). Sharing stories may also be a way to shed light on choices and structures that are perpetuating racial and gendered norms in the program, online environment, or within the homes of students. This may help students make conscious decisions to improve personal actions and to address cultural and social barriers.

\section{Conclusion}

Results of this study indicated both personal (i.e., gender, race, age, marital status, and presence of children in the home) and program variables (i.e., stage in the program, the presence of synchronous interaction, use of a cohort model, and participation in an orientation) influence program integration of the online doctoral students in this study. Further, the variables of gender, race, being part of a cohort, and participating in synchronous meetings made significant individual contributions in explaining the variance in student satisfaction with program integration. Nearly $30 \%$ of the variability in program integration was predicted by the identified personal and program variables. While this study provides insightful findings and implications for doctoral faculty and their role in supporting doctoral students' program integration, it is important to acknowledge this study has limitations and further research is needed.

We delimited this study to online doctoral students in professional EdD programs where at least $80 \%$ of the program was delivered online. Further research should be conducted with a wider audience to improve generalizability. Consideration should be given to exploring additional non-STEM and STEM online programs as well as $\mathrm{PhD}$ programs.

This was a correlational study that used multiple regression analysis. Thus, only an association among variables can be asserted. Further research and more complex modeling are needed to understand the interaction of all the variables in the model, especially those that were not significant individual contributors. This research only examined five personal and four program variables. Other personal and program factors should be examined. For example, selfmotivation, employment obligations, and financial obligations have been identified as potential potentially influencing integration of doctoral and online students (Bean \& Metzner, 1985; Earl-Novell, 2006; Ivankova \& Stick, 2007, Spaulding \& Rockinson-Szapkiw, 2012; Rovai, 2003; Tinto, 1993; Wao \& Onwuegbuzie, 2011). 
Experimental research is needed to examine the cause and effect relationship between specific doctoral program experiences and students' program integration. Additionally, variables in this study were measured using self-report items; thus, self-report bias may have been present. For example, participants may have avoided negative judgments and agreed with the statements more than they disagreed (Couch \& Keniston, 1960). Future research may explore objective measures of program evaluation. Finally, consideration should be given to a longitudinal study to identify how personal and program factors influence program integration as students navigate the program stages.

Doctoral attrition rates are high (Cassuto, 2013; Council of Graduate Schools, 2008), and rates increase in online programs (Holder, 2007; Rovai, 2002; Terrell et al., 2009). The literature is clear that integration is a predictor of doctoral student persistence (Ivankova \& Stick, 2007; Lovitts, 2001; Rockinson-Szapkiw et al., 2016; Wao \& Onwuegbuzie, 2011). The results of this study add insight into the personal and program variables that influence program integration of doctoral students studying at a distance. Doctoral conferring institutions have an obligation to identify factors and develop interventions that promote program integration of their online doctoral students. Identifying specific personal and program variables, and how they influence the program integration of doctoral students in online programs, can go a long way in reducing the high online doctoral student attrition rates. 


\section{References}

Ali, A., \& Kohun, F. (2006). Dealing with isolation feelings at IS doctoral programs. International Journal of Doctoral Studies, 1, 21-33. Retrieved from http://ijds.org/Volume1/IJDSv1p021-033Ali13.pdf

Ali, A., \& Kohun, F. (2007). Dealing with social isolation to minimize doctoral attrition: A fourstage frame-work. International Journal of Doctoral Studies, 2(1), 33-49.

Ames, C., Berman, R., \& Casteel, A. (2018). A preliminary examination of doctoral student retention factors in private online workspaces. International Journal of Doctoral Studies, 13, 79-107.

Bawa, P. (2016). Retention in online courses: Exploring issues and solutions-A literature review. SageOpen, 1-11, DOI: 10.1177/2158244015621777. Retrieved from https://journals.sagepub.com/doi/full/10.1177/2158244015621777\#articleCitationDownlo adContainer

Bean, J. P. \& Metzner, B. S. (1985). A conceptual model of nontraditional student attrition. Review of Educational Research, 55, 485-540.

Berry, S. S. (2017). Student support networks in online doctoral programs: Exploring nested communities. International Journal of Doctoral Studies, 12, 33-48.

Bhandari, N. A., MacDonald, B. L., Martin, J. M., Modena, A., Simmons, J. M., Turner, W. D., \& Asselin, S. (2013). Professional seminar: Valuing a one-credit course through the lens of doctoral students. International Journal of Teaching and Learning in Higher Education, 25, 346-357

Bista, K., \& Cox, D. (2014). Cohort-based doctoral programs: What we have learned over the last 18 years. International Journal of Doctoral Studies, 9, 1-20. Retrieved from http://ijds.org/Volume9/IJDSv9p001020Bista0425.pdf

Bowen, W., \& Rudenstine, N. (1992). In pursuit of the Ph.D. Princeton, NJ: Princeton University Press.

Braxton, J. M., \& Lien, L. A. (2000). The viability of academic integration as a central construct in Tinto's interactionalist theory of college student departure. In J. M. Braxton (Ed.), Reworking the student departure puzzle (pp. 9-18). Nashville, TN: Vanderbilt University Press.

Braxton, J. M., Sullivan, A. S., \& Johnson, R. (1997). Appraising Tinto's theory of college student departure. In J. Smart (ed.), Higher education: Handbook of theory and research, vol. 12 (pp. 107-164). New York, NY: Agathon.

Brown, L., \& Watson, P. (2010). Understanding the experiences of female doctoral students. Journal of Further and Higher Education, 34(3), 385-404. doi:10.1080/0309877X.2010.484056 
Identifying Significant Personal and Program Factors that Predict Online EdD Students' Program Integration

Carter, S., Blumenstein, M., \& Cook, C. (2013). Different for women? The challenges of doctoral studies. Teaching in Higher Education, 18(4), 339-351.

Cassuto, L. (2013). Ph.D. attrition: How much is too much? The Chronicle of Higher Education. Retrieved from http://chronicle.com/article/PhD-Attrition-How-Much-Is/140045/

Castelló, M., Pardo, M., Sala-Bubaré, A., \& Suñe-Soler, N. (2017). Why do students consider dropping out of doctoral degrees? Institutional and personal factors. Higher Education, 116. https://doi.org/10.1007/s10734-0160106-9

Cohen, J. (1992). A power primer. Psychological Bulletin, 112(1), 155.

Couch, A. \& Keniston, K. (1960). Yeasayers and nay-sayers: Agreeing response set as a personality variable. Journal of Abnormal and Social Psychology, 60, 151-174.

Council of Graduate Schools. (2008). Ph.D. completion project: Program completion and attrition data. Retrieved from http://www.phdcompletion.org/quantitative/book1 quant.asp

Council of Graduate Schools. (2012). Attrition and completion. Retrieved from http://www.cgsnet.org/attrition-and-completion

Dabney, K. P., \& Tai, R. H. (2013). Female physicist doctoral experiences. Physical Review Special Topics-Physics Education Research, 9(1). doi:010115-1-010115-10.

Davidson, C., \& Wilson, K. (2013). Reassessing Tinto's concepts of social and academic integration in student retention. Journal of College Student Retention: Research, Theory \& Practice, 15(3), 329-346. doi:10.2190/CS.15.3. b

DeVellis, R.F. (2003). Scale development: Theory and application ( $2^{\text {nd }}$ ed.). Thousand Oak, CA: Sage Publication.

Di Pierro, M. (2007). Excellence in doctoral education: Defining best practices. College Student Journal, 41(2), 368-375.

Earl-Novell, S. (2006). Determining the extent to which program structure features and integration mechanisms facilitate or impede doctoral candidate persistence in mathematics. International Journal of Doctoral Studies, 1,45-57. Retrieved from http://www.ijds.org/Volume1/IJDSv1p045-057Earl16.pdf

Ellis, E. M. (2001). The impact of race and gender on graduate school socialization, satisfaction with doctoral study, and commitment to degree completion. The Western Journal of Black Studies, 25, 30-45.

Erikson, R.J. (2005). Why emotion work matters: Sex, gender, and the division of household labor. Journal of Marriage and Family, 67(2), 337-351. 
Fuller, J., Risner, M., Lowder, L., Hart, M., \& Bachenheimer, B. (2014). Graduates' reflections on an online doctorate in educational technology. TechTrends: Linking Research \& Practice to Improve Learning, 58(4), 73-80.

Gardner, S. K. (2009). Student and faculty attributions of attrition in high and low-completing doctoral programs in the United States. Higher Education, 58, 97-112. https://doi.org/10.1007/s10734-008-9184-7

Gardner, S. K. (2010). Contrasting the socialization experiences of doctoral students in high and low completing departments: A qualitative analysis of disciplinary contexts at one institution. The Journal of Higher Education, 81(1), 61-81.

Gardner, S. K. (2013). Women faculty departures from a striving institution: Between a rock and a hard place. Review of Higher Education, 36, 349-370.

https://doi.org/10.1353/rhe.2013.0025

Garrison, R. D., \& Arbaugh, J. B. (2007). Researching the community of inquiry framework: Review, issues, and future directions. The Internet and Higher Education 10(3), 157-172. doi:10.1016/j.iheduc.2007.04.001

Gay, G. (2004). Navigating marginality en route to the professoriate: Graduate students of color learning and living in academia. International Journal of Qualitative Studies in Education, 17, 265-288. doi:10.1080/0951839031000165390

Gildersleeve, R. E., Croom, N. N., \& Vasquez, P. L. (2011). “Am I going crazy?!”: A Critical Race Analysis of doctoral education. Equity \& Excellence in Education, 44(1), 93-114.

Gittings, G., Bergman, M., Shuck, B., Rose, K. (2018). The impact of student attributes and program characteristics on doctoral degree completion. New Horizons in Adult Education and Human Resource Development, 30, 3-22.

Golde, C. M. (2005). The role of the department and discipline in doctoral student attrition: Lessons from four departments. The Journal of Higher Education, 76, 669-700. https://doi.org/10.1353/jhe.2005.0039

Grover, V. (2007). Successfully navigating the stages of doctoral study. International Journal of Doctoral Studies, 2, 9-21. https://doi.org/10.28945/54

Herbert, M. (2006). Staying the course: A study in online student satisfaction and retention. Online Journal of Distance Learning Administration, 9(4). Retrieved from http://www.westga. edu/ distance/ojdla/winter94/herbert94.htm

Heyman, E. (2010). Overcoming student retention issues in higher education online programs: A Delphi study (Doctoral dissertation). Retrieved from ProQuest Dissertations and Theses database. (ProQuest document ID: 748309429). Retrieved from http://search.proquest.com/docview/748309429?accoun tid=13360

Hochschild, A. \& Machung, A. (2012). The second shift: working families and the revolution at home. New York, N.Y.: Penguin Books. 
Identifying Significant Personal and Program Factors that Predict Online EdD Students' Program Integration

Holder, B. (2007). An investigation of hope, academics, environment, and motivation as predictors of persistence in higher education online programs. The Internet and higher education, 10(4), 245-260.

Holmes, J. L., \& Rockinson-Szapkiw, A. J. (2019, in press). The development and validation of the Distance Doctoral Program Integration Scale. Online Learning Journal.

Hyun, J. K., Quinn, B. C., Madon, T., \& Lustig, S. (2006). Graduate student mental health: Needs assessment and utilization of counseling services. Journal of College Student Development, 47(3), 247-266.

Ivankova, N. V., \& Stick, S. L. (2005). Collegiality and community-building as a means for sustaining student persistence in the computer-mediated asynchronous learning environment. Online Journal of Distance Learning Administration, 8(3).

Kramarae, C. (2003). Gender equity online, when there is no door to knock on. In M. G. Moore \& W. G. Anderson (Eds.), Handbook of Distance Education (pp. 261-272). Mahwah, NJ; Erlbaum.

Lee, A., Green, G. \& Brennan, M. (2000), Organisational knowledge, professional practice and the professional doctorate at work. In I. Garrick \& C. Rhodes (Eds), Research and Knowledge at Work: Perspectives, Case Studies and Innovative Strategies (pp. 117-136). London: Routledge.

Lei, S., Gorelick, D., Short, K., Smallwood, L., \& Wright-Porter, K. (2011). Academic cohorts: Benefits and drawbacks of being a member of a community of learners. Education, 131(3), 497-504. Retrieved from http://eric.ed.gov/?id=EJ996368

Leijen, Ä., Lepp, L., \& Remmik, M. (2016). Why did I drop out? Former students' recollections about their study process and factors related to leaving the doctoral studies. Studies in Continuing Education, 38(2), 129-144. https://doi.org/10.1080/0158037X.2015.1055463

Litalien, D., \& Guay, F. (2015). Dropout intentions in PhD studies: A comprehensive model based on interpersonal relationships and motivational resources. Contemporary Educational Psychology, 41, 218-231. https://doi.org/10.1016/j.cedpsych.2015.03.004

Lott, J. L., Gardner, S., \& Powers, D. A. (2009). Doctoral student attrition in the STEM fields: An exploratory event history analysis. Journal of College Student Retention: Research, Theory \& Practice, 11(2), 247-266.

Lovitts, B. E. (2001). Leaving the ivory tower: The causes and consequences of departure from doctoral study. Rowman \& Littlefield.

Lovitts, B. E. (2008). The transition to independent research: Who makes it, who doesn't, and why. The Journal of Higher Education, 79, 296-325. https://doi.org/10.1353/jhe.0.0006

Marso, L. J. (2006). Feminist thinkers and the demands of femininity: The lives and work of intellectual women. New York: Routledge, Taylor \& Francis. 
Identifying Significant Personal and Program Factors that Predict Online EdD Students' Program Integration

Maul, J., Berman, R., \& Ames, C. (2018). Exploring the psychological benefits of using an emerging video technology to coach and retain doctoral learners. International Journal of Doctoral Studies, 13, 49-78. https://doi.org/10.28945/3954

Mason, M. \& Maxwell, T. (2003). From first to second generation professional doctorate. Studies in Higher Education, 28(3), 279-291.

Moore, M. G. (1989). Editorial: Three types of interaction. The American Journal of Distance Education, 3(2), 1-7. doi:10.1080/08923648909526659

Motte, K. (2019). A grounded theory study of the ideal components of an orientation for a distance education doctor of education program: The perspectives of students, non-per sisters, alumni, faculty, and administrators. Unpublished doctoral dissertation, Liberty University, Lynchburg, VA.

Nettles, M. T., \& Millett, C. M. (2006). Three magic letters: Getting to Ph.D. Baltimore, MD: John Hopkins University Press.

National Science Foundation. (2019). Women, minorities, and persons with disabilities in science and engineering. Retrieved from https://ncses.nsf.gov/pubs/nsf19304/digest

O’Meara, K., Griffin, K. A., Kuvaeva, A., Nyunt, G., \& Robinson, T. (2017). Sense of belonging and its contributing factors in graduate education. International Journal of Doctoral Studies, 12, 12, 251-279. https://doi.org/10.28945/3903

Oswalt, S. B., \& Riddock, C. C. (2007). What to do about being overwhelmed: Graduate students, stress and university services. College Student Affairs Journal, 27(1), 24.

Ostrove, J. M., Stewart, A. J., \& Curtin, N. L. (2011). Social class and belonging: Implications for graduate students' career aspirations. The Journal of Higher Education, 82(6), 748774.

Perry, J. A. (2013). Carnegie Project on the Education Doctorate: The education doctorate-a degree for our time. Planning and Changing, 44(3), 113-126.

Provident, I. M., Salls, J., Dolhi, C., Jodi, S., Mattila, A., \& Eckel, E. (2015). Design of an online curriculum promoting transformative learning in post professional doctoral students. Online Learning Journal, 19(3), 1-16.

Postmes, T., Haslam, S. A., \& Jans, L. (2013). A single-item measure of social identification: Reliability, validity, and utility. British Journal of Social Psychology, 52(4), 597-617.

Rademaker, L., Duffy, J. O., Wetzler, E., \& Zaikina-Montgomery, H. (2016). Chair perceptions of trust between mentor and mentee in online doctoral dissertation mentoring. Online Learning Journal, 20(1), 1 - 13.

Richardson, H. A., Simmering, M. J., \& Sturman, M. C. (2009). A tale of three perspectives: Examining post hoc statistical techniques for detection and correction of common method variance. Organizational Research Methods. 
Identifying Significant Personal and Program Factors that Predict Online EdD Students' Program Integration

Rockinson-Szapkiw, A. J. (2010). Improving doctoral candidates' persistence in the online dissertation process. Retrieved from https://digitalcommons.liberty.edu/educ fac pubs/184

Rockinson-Szapkiw, A. J. (2019). Toward understanding factors salient to doctoral students' persistence: The development and preliminary validation of the Academic-Family Integration Inventory. International Journal of Doctoral Studies, 14, 237-258. https://doi.org/10.28945/4248

Rockinson-Szapkiw, A. J., Baker, J. D., Neukrug, E., Hanes, J. (2010). The efficacy of computermediated communication technologies to augment and support effective online helping profession education. Journal of Technology in Human Services, 28, 161-177.

Rockinson-Szapkiw, A. J., Sosin, L. S., \& Spaulding, L. (2018). Does family matter? A phenomenological inquiry exploring the lived experiences of women persisting in distance education, professional doctoral programs. International Journal of Doctoral Studies, 13, 497-515. https://doi.org/10.28945/4157

Rockinson-Szapkiw, A. J., \& Spaulding, L. S. (2014). Navigating the doctoral journey: A handbook of strategies for success. Lantham, MD: Rowman \& Littlefield.

Rockinson-Szapkiw, A. J., Spaulding, L. S., \& Spaulding, M. T. (2016) Identifying significant integration and institutional factors that predict online doctoral persistence. The Internet and Higher Education, 31, 101-112.

Rockinson-Szapkiw, A. J., Spaulding, L. S., \& Lunde, R. M. (2017). Women in distance doctoral programs: How they negotiate their identities as mothers, professionals, and academics in order to persist. International Journal of Doctoral Studies, 12(7), 50-72. Retrieved from http://ijds.org/Volume12/IJDSv12p049-072Szapkiw2916.pdf

Rockinson-Szapkiw, A. J., Spaulding, L. S., Swezey, J. A., \& Wicks, C. (2014). Poverty and persistence: A model for understanding individuals' pursuit and persistence in a doctor of education program. International Journal of Doctoral Studies, 9, 181-190 Retrieved from http://ijds.org/Volume9/IJDSv9p181-203Rockinson0606.pdf.

Rockinson-Szapkiw, A. J., \& Walker, V. L. (2009). Web 2.0 technologies: Facilitating interaction in an online human services counseling skills course. Journal of Technology in Human Services, 27, 175-193.

Rosenblatt, H. S., \& Christensen, C. (1993). "Welcome to the whole family": A graduate student orientation. College Student Journal, 27, 502-505.

Rosser, S. V., \& Lane, E. O. N. (2002). Key barriers for academic institutions seeking to retain female scientists and engineers: Family-unfriendly policies, low numbers, stereotypes, and harassment. Journal of Women and Minorities in Science and Engineering, 8(2). https://doi.org/10.1615/JWomenMinorScienEng.v8.i2.40 
Identifying Significant Personal and Program Factors that Predict Online EdD Students' Program Integration

Rovai, A. P. (2002). Sense of community, perceived cognitive learning, and persistence in asynchronous learning networks. Internet and Higher Education, 5, 319-332.

Rovai, A. P. (2003). In search of higher persistence rates in distance education online programs. Internet and Higher Education, 6, 1-16.

Rovai, A. P. (2014). Creating a scholarly community and collegial support system. In A. J. Rockinson-Szapkiw \& L. S. Spaulding (Eds.), Navigating the doctoral journey: A handbook of strategies for success (pp. 9-18). Lantham, MD: Rowman \& Littlefield.

Shea, P., Li, C., \& Pickett, A. (2006). A study of teaching presence and student sense of learning community in fully online and web-enhanced college courses. Internet and Higher Education, 9(3), 175-190.

Smith, B. (2010). E-learning technologies: A comparative study of adult learners enrolled on blended and online campuses engaging in a virtual classroom (Doctoral dissertation). Retrieved from ProQuest Dissertations and Theses database

Smith, R. L., Maroney, K., Nelson, K. W., Abel, A. L., \& Abel, H. S. (2006). Doctoral programs: Changing high rates of attrition. The Journal of Humanistic Counseling, 45(1), 17.

Shulman, L., (2010). Doctoral education shouldn't be a marathon. Chronicle of Higher Education, B9-B12.

Tanaka, M., \& Watanabea, Y. (2012). Academic and family conditions associated with intrinsic academic motivation in Japanese medical students: A pilot study. Health Education Journal, 71, 358-364. https://doi.org/10.1177/0017896911401004

Taub, D., \& Komives, S. R. (1998). A comprehensive graduate orientation program: Practicing what we preach. Journal of College Student Development, 39, 394-398.

Teng, D., Chen, N., Kinshuk, \& Leo, T. (2012). Exploring students' learning experience in an international online research seminar in the Synchronous Cyber Classroom. Computers \& Education, 58, 918-930.

Terrell, S. R., Snyder, M. M., \& Dringus, L. P. (2009). The development, validation, and application of the doctoral student connectedness scale. Internet and Higher Education, 112-116.

Terrell, S. R., Snyder, M. M., \& Dringus, L. P. (2012). Grounded theory of connectivity and persistence in a limited residency doctoral program. The Qualitative Report 17(62), 1-14.

Terrell, S. (2005). A longitudinal investigation of the effect of information perception and focus on attrition in online learning environments. The Internet and Higher Education, 8(3), 213-219

Tinto, V. (1975). Dropout from higher education: a theoretical synthesis of recent research. Review of Educational Research, 45(1), 89-125. 
Identifying Significant Personal and Program Factors that Predict Online EdD Students' Program Integration

Tinto, V. (1987). Leaving college. Chicago, IL: The University of Chicago Press.

Tinto, V. (1993). Leaving college: Rethinking the causes and cures of candidate attrition (2nd ed.). Chicago, IL: The University of Chicago Press.

Tinto, V. (2006-2007). Research and practice of student retention: what next? Journal of College Student Retention: Research, Theory \& Practice, 8(1), 1-20.

Tinto, V. (2012). Completing college: Rethinking institutional action. Chicago, IL: University of Chicago Press.

Ward, K. A., \& Wolf-Wendel, L. E. (2017). Mothering and professing: Critical Choices and the Academic Career. NASPA Journal About Women in Higher Education, 10(3), 229-244, doi: 10.1080/19407882.2017.1351995

Warner, R. M. (2013). Applied statistics: from bivariate through multivariate techniques: from bivariate through multivariate techniques. CA: Sage Publications.

Wao, H. O., \& Onwuegbuzie, A. J. (2011). A mixed research investigation of factors related to time to the doctorate in education. International Journal of Doctoral Studies, 6, 115-134. Retrieved from http://ijds.org/Volume6/IJDSv6p115-134Wao320.pdf

Zahl, S. B. (2015). The impact of community for part-time doctoral students: How relationships in the academic department affect student persistence. International Journal of Doctoral Studies, 10, 301-321. Retrieved from http://ijds.org/Volume10/IJDSv10p301$\underline{\text { 321Zah10672.pdf }}$

Zhao, C. M., Golde, C. M., \& McCormick, A. C. (2007). More than a signature: How advisor choice and advisor behaviour affect doctoral student satisfaction. Journal of Further and Higher Education, 31, 263-281. https://doi.org/10.1080/03098770701424983 